DOI: 10.1515/ausfm-2015-0022

\title{
Intermediality and Reflexivity in Andrzej Żuławski's Fidelity
}

\author{
Adrián Bene \\ University of Pécs (Hungary) \\ E-mail: beneadrian@gmail.com
}

\begin{abstract}
The paper focuses on a characteristic of Andrzej Żuławski's aesthetics which has been ignored by most of the critics who emphasized the impact of surrealism and the taste for provocation in his cinema. Meanwhile, the œuvre's French period is obviously characterized by self-reflexivity and media-reflexivity, autobiographical and literary background references. In these film dramas, the topic of love, beauty and artistic values are interconnected with a sophisticated narrative strategy using intermediality and intertextuality in a complex way. In Fidelity (La Fidelité, 2000), Żuławski put photography and literature in focus again in order to express thoughts and emotions in their complexity, surpassing the limitations of the linear narrative. A certain semiotic double-codedness is provided by either intertextual references or the hidden meanings based on the symbolic language of flowers, used as diegetic metaphors. Moreover, Żuławski thematizes photography that makes us conscious of our experiences from an aesthetic distance, even in an ironic manner.
\end{abstract}

Keywords: self-reflexivity, intermediality, adaptation, intertextuality, photography, poetry, language of flowers, irony.

\section{Reflexivity in Żuławski}

Andrzej Żuławski’s cinema is usually interpreted by highlighting such thematic leitmotifs as cruelty, hysteria, anarchism, mad love, and absolute liberty. Robert Hammond compares Żuławski to Walerian Borowczyk "in his taste for provocation and spectacular effects" (Ford and Hammond 2005, 148) claiming that they "squandered their gifts on unworthy and sensational productions" (Ford and Hammond 2005, 144). Michael Goddard refers to the shortcomings of contextualization in the third generation of Polish cinema, in the Polish New Wave, as well as to the focusing on surrealist characteristics (Goddard and Mazierska 2014, 237-238). Investigating the subversive aspect of Żuławskian 
cinema, Goddard underlines that the French period is "aesthetically and stylistically distinct from his Polish work" (Goddard and Mazierka 2014, 248), the latter being influenced by some of the work of Jean-Luc Godard, at least by Contempt (Le Mépris, 1963) and Pierrot le fou (1965), and "was certainly inspired by Godard's disregard for conventional narrative structures” (Goddard and Mazierska 2014, 238). Goddard stresses the importance of performativity and intertextuality in Żuławski's French cinema from The Most Important Thing: Love (L'Important c'est d'aimer, 1975) to Fidelity (La Fidelité, 2000). Based on the above-mentioned narrative aspect of subversivity, I shall study Fidelity in terms of reflexivity, taking Żuławski's earlier French cinema into consideration. In these adaptations, intertextuality and aesthetic self-reflection are constantly pivotal, and so is intermediality.

Żuławski has an original cinematic voice, as Michael Atkinson puts it: "Few other filmmakers have maintained, come hell or high water, as defiantly consistent a voice, and no one's cinematic voice is as divisive, as ludicrously anarchic, as viciously overwrought" (Atkinson 2008, 80). Here I shall try to map out the narrative structure of this phenomenon, characterized by biographical and intertextual references, self-reflexivity, intermediality and the topic of voyeurism. It is well known that Żuławski is also a prolific author and, as a young student he was working as a photographer, so "his films and his life are woven with literature, paintings, music." ${ }^{1}$ Cinematic allusions and visual quotations are also quite usual in these films, with a purpose of aesthetic reflection. There are several allusions to the typical scenes and motives of Buñuel, Godard, Truffaut, Antonioni, Makavejev, among others. A special case is the opera film, such as his Boris Godunov (1989), and the biographical film on Chopin and Georges Sand (The Blue Note - La note bleue, 1991), both being the intermedial terrain of aesthetic self-reflection. Hereby must we mention the role of music in Żuławski's cinema, usually composed by Andrzej Korzynski. Filmmaking and photography as mise en abymes ${ }^{2}$ are present in The Most Important Thing: Love, in The Public Woman, (La femme publique, 1984), and theatrical spectacle has the same function in Mad Love (L'Amour braque, 1985). As we will see, in Fidelity intermediality and intertextuality are also connected very closely.

Photography is not just a part of his world and his films, but "film is photography," as Żuławski puts it. It obviously implies the fact of self-reflexivity, since at least from

1 See the Filmcomment's interview with Żuławski in 2012 (Barton-Fumo 2012).

2 On the transcendental mise en abyme through which an interpretation of the frame-story or the reality itself is provided, see Dällenbach 1989, 107-116. 
the 1960s photography as an art form has been the main field of self-referentiality, which metaphorically drives to a general aesthetic self-reflection. Similarly, filmmaking plays an essential role in the plot of his films, as well as theatre or poetry. In the opening scene of The Most Important Thing: Love, there is a film shoot going on, and one can be seen also in The Public Woman. Moreover, the world of cinema is permanently put in focus in a reflexive Godardian manner, showing Hollywood movie posters (as potential mise en abymes of the plot at the same time). Furthermore, the main characters are a photographer and an actress; both are compelled to prostitute themselves as artists, which has a symbolic meaning. The husband of Nadine, the actress has the hobby of collecting movie-photos. It is closely related to the aesthetic problem of the visual and narrative representation of reality, evoking among others Antonioni's film classic Blow-Up (1966). The central role of photography helps the viewer understand the self-reflexive character which emphasizes the fact that life often hides the truth that only the artwork can help us discover. To quote Peter Goldman: "Antonioni suggests that meaning is discovered in the creative process rather than being determined by a performed authorial intentionality. The mimesis of empirical reality is subordinated to a collaborative process involving the audience and actors" (Goldman 2008). The credit for this insight also goes to Żuławski, whose oeuvre has a taste of concept art, evoking altogether the performance and the orgiastic Vienna Actionism (Wiener Aktionismus) of Hermann Nitsch and others. The strong theatricality, through the body and the facticity of bodily existence points to the simultaneously subjective and conventional character of every representation, necessarily distorting and interpreting the reality. Besides, it is obvious that Antonin Artaud's theater of cruelty and Jerzy Grotowski’s "poor theatre” had a major influence on Żuławski (Atkinson 2008, 81). Ecstatic and cathartic states of mind are often represented in Żuławski’s cinema, generally in an absurd, grotesque or surrealistic way. Atkinson points out that "his sensibility is in-grown surrealist - not in terms of imagery (which is most often grounded in absurd) but in terms of emotional eruption, disorienting texture, mad-love worship" (Atkinson 2008, 81). This irrationality is always connected to transgression and subversion, setting freedom against social order.

In Mad Love the scene is set in 1968 Paris, and starts with a grotesque bank robbery committed in Disney costumes just as if it was a masquerade. The subversive carnival-like performances suggest that the only way of social revolution is being an outsider - as madman, poet, or criminal. As an adaptation of Dostoievsky's Idiot, the film focuses on the possibility of revolution. Leon, akin to Mishkin, is an idiot, which means a kind of purity and innocence here, while 
the others need drugs or madness to be outside the order. The aesthetic reflection appears in the form of a theatrical mise en abyme presenting Chekhov's Seagull as the adequate representation of reality.

The problem of realism is linked to extremity and hysterical eccentricity in the erotic photo shoot scenes of The Public Woman, a real metafilm, a film about making film that starts with an audition for an adaptation of Dostoievsky's The Possessed. The date 1968 allows on the one hand a social and philosophical interpretation focusing on violence and social change (there are several allusions to Sartre and existentialism), and on the other hand, a reflection on the history of the European cinema of the 1960s, including Godard, Truffaut, Antonioni and Forman. Meanwhile, the character of Lucas Kessling, the director, can be seen as a fictional analogue of Żuławski himself. Thus, reflexivity, literary allusions and biographical references are common in Żuławski's French cinema; the film language used in Fidelity is an acquired and well-mastered one.

\section{Photography and Realism in Fidelity}

Fidelity is an autobiographical fiction and, at the same time, a cinematic adaptation, more precisely, a palimpsest-like re-writing of the famous love story of La Princesse de Clèves wrote by Madame de La Fayette in the seventeenth century. (It was presented one year after the adaptation of Mme Lafayette's novel by Manoel de Oliveira - The Letter [La Lettre, 1999]). The interconnection of autobiography and artistic fiction lies in the fact that the young and beautiful, adulterous photographer, Clélia is impersonated by Sophie Marceau, Żuławski’s wife, who finally left him in 2001. In the film she draws to a paparazzi colleague called Némo. They work for the tabloid La Vérité, therefore the visual representation of reality is in the focus of the picture, in an ironic way. This irony gains a tragic self-ironic accent by the W. H. Auden poems often cited in the film drama, the poet being the favourite one of Clèves, Clélia's abandoned husband. Thus, we have to consider the intermedial surplus meaning constituted by linking novel, poetry, film, music, and photography together, which represents the interconnection of reality, fiction, desires and media simulacra. Fidelity is obviously linked to Żuławski's autobiographical novel, Infidelité (Infidelity), in which he wrote the story of their break-up. Thus, the film has a manifold meaning, implying a biographical "reading," in which the viewer has to solve a puzzle to grasp Żuławski's thoughts and feelings about the love between himself and his wife. Intertextuality and intermediality both serve as a mask to hide the factual 
and too personal character of the story. Therefore, he elaborates a complex, at once cryptological and double-coded communication.

This double-codedness is represented by the intermedial and multimodal flowerpieces, being a form of still life. The language of flowers is often used in literature, but Żuławski combines this symbolic surplus meaning with the intermedial aesthetic self-reflection represented by photography. It results in a polysemic structure, since nearly every flower has multiple associations, and points out the viewer's hermeneutical task. Flower-pieces appear several times during the film, providing a structure of hidden meanings behind the surface of the - basically literary, that is, linguistic - narrative. It makes his words on images more plausible: "This expression is not telling you things with words but making you see it" (Barton-Fumo 2012). First, Clélia meets Clèves in a flower shop, and soon, during having sex with him, in a symbolic manner she treads on the bunch made for Clèves's engagement. [Fig. 1.] In the shop, Clélia askes Clèves to allow her to take a photo of the bunch of lilies, and these flowers are the symbol of purity and innocence. ${ }^{3}$ [Fig. 2.] It is obliquely ironic when she asks if it is for a funeral. For the second time, Clélia takes photos of a bunch of gerberas, which may symbolize love, in general, but here they do it in an ambiguous way because red ones, like red roses, may refer to admiration and desire, while white ones may imply pure love and innocence. In this scene, there is a special, simultaneously intermedial and intertextual effect pointing out the limits of narrativization: when Auden's famous poem, August 1968 is being recited (in French) while shooting flower arrangements:

The Ogre does what ogres can,

Deeds quite impossible for Man,

But one prize is beyond his reach,

The Ogre cannot master Speech:

About a subjugated plain,

Among its desperate and slain,

The Ogre stalks with hands on hips,

While drivel gushes from his lips. (Auden 1969, 88.)

For the third time, flowers get into focus in the midst of the story, after the marriage of Clélia and Clèves. Clélia feels perplexed because of the strong desire she feels for Nemo, a young paparazzo. She takes photos of flowers that express

3 An alphabetic catalogue of meanings and sentiments with a bibliography of flower symbolism is available online: http://www.languageofflowers.com/ 
her emotions in a symbolic way. She shoots five bunches one after another. The first one mostly contains pink Stargazer lilies with white gardenias: the first means wealth and prosperity while the latter stand for secret love. [Fig. 3.] This combination carries an obvious tension, intensified by the next shots. The second bunch is made of red roses and huge red celosia cockscombs (brain flowers), both referring to burning love (the latter's Greek etymology - kelos - is flame), while celosia also means silliness. [Fig. 4.] In the middle of the bunch, there are also some asters, which symbolize patience, but this flower is also indicative of the love of variety. These pink asters could also mean that "I will never forget you." In the third bunch, there are sunflowers, which may have several meanings, such as devotion, hospitality, pure thoughts, or adoration, dedicated love, or even haughtiness. [Fig. 5.] The next bunch is full of pink roses, which indicate an affection that may turn into deeper love. There is only one white rose, on the periphery, while two yellow roses appear, which represent infidelity, and a red one, which - as mentioned above - refers to passionate love. [Fig. 6.] Finally, Clélia is becoming more and more perturbed while shooting a red anthurium, which symbolizes hospitality or happiness. [Fig. 7.] She is obviously thinking about Nemo and she is looking for him, hoping that he is on the lurk again on the neighbour's rooftop. In the end, after his husband's death, Clélia takes photos of an aloe in a strange convent where joy is the main task for the nuns, even if it is enforced and unspontaneous. Aloe, the lily of the desert, symbolizes grief and pain as well as healing and life, but can also refer to eternal life, implying religious devotion, and to the opposite, to the primacy of earthly life. [Fig. 8.]

Flowers "can be totally shameless" says Clélia in an interview, just as if responding to her mother's words concerning the principle of honour. On this level, there is another double-coded communication, the one of Żuławski as an implied author. The Princess of Cleves as a hypotext gives an ironic accent to the voice of the left lover known from the biography. The novel focuses on the virtue of fidelity, while love in the real life leads to infidelity. Thus, the idealism of a lover like Clèves - or, by analogy, like Żuławski - can be interpreted as an either tragic or comic fail. As we see, the intertextual irony constitutes a voice in which the "implied author" of the film cannot be independent from the biographical person of the director. What makes possible to apply this narratological framework to cinema - one can ask oneself. This is made possible by the intermedial and intertextual features which express a metaverbal reflection, in a double-coded way. Besides the iconic surplus dimension, flowers, just like poetry, have an autoreferential aesthetic function and a synesthetic potential to make us feel what 
cannot be narrativized. This metalanguage unites the metaverbal and metavisual features analysed by Marina Grishakova: "Whereas the metavisual text refers to an inadequate or virtual verbal counterpart of the visual representation, the excess of verbalization in the metaverbal text is meant to compensate for a lack of visual representation - what the narrator and the characters are trying but unable to see, or what they are only imagining to be real" (Grishakova 2010, 323). This narratological approach seems to be fit for the Żuławskian cinema, as well as for a Dickens novel (López-Varela and Khaski Gaglia 2013). Since the adapted work was the first psychological novel, the director had to represent the characters' inner thoughts and emotions in every possible way, let alone the supposed confessional intention. Poetry, still images, flower language and literary background references express the complex psychology of love.

Photography as a recurring reflexive theme of Żuławski permanently appears in Fidelity. At the end of the opening scene, Clélia suddenly takes a photo of his mother, to make her an aesthetic object, in order to be able to keep a distance from her. As an artistic photographer, she points to the hollowness and impersonality of life in her photographs by making them out of focus, thus changing figures into ghost images. [Fig. 9.] (For reasons of space, we do not discuss the transcendent elements of the film, though it is important to mention that ghosts often appear to Clélia.) She tries to be objective when representing reality, while starts to work in mass media, for a tabloid newspaper. Obviously, both imply related aesthetic problems, that of realism and that of mass mediatedness. The blurred shots of the hockey match and Clélia's words that every good photo is "méchante" (that is, malicious, cruel) are in accordance with Żuławski's earlier aesthetics. This cruelty consists in an estrangement, an artificial distance from the faceless, unidentifiable bodies. Once again, the problem of realism has a reference to the Blow-Up scene on deciphering a modern painting. Goldman associates it with Antonioni's statement on reality in his 1964 essay: "We know that under the revealed image there is another one which is more faithful to reality and under this one there is yet another and again another under this last one, down to the true image of that absolute, mysterious reality that no one will ever see. Or perhaps, not until the decomposition of every image, of every reality" (Antonioni 2007, 63).

Contrary to these blurred photos, the ones taken by Némo show "the truth" of flesh-and-bone reality, a sort of "cruel science of man." [Fig. 10.] As MacRoi's lover puts it: "The real is photographed as it is." For her naturalism, Clélia's style is "arty-farty" ("artisme"). For Clélia, to photograph the world means defending herself against it. [Fig. 11.] 
It is worth adding that realism in the age of computer images is quite a problematic term. Analysing the difference between traditional and digital photography, Göran Sönesson argues that the "synthetic image" consisting of pixels involves a disruption separating the content and its expression (Sönesson 2003, 3). Akin to language, computer image is made up by arbitrary, endlessly repeatable elements, thus it loses either the iconic or the indexical link to reality (Sönesson 2003, 5). Besides, it is the image which constitutes reality, opening up a virtual dimension.

Sönesson distinguishes three types by which pictures can be described (Sönesson 1996). He emphasizes the fact that "construction types, such as oil paintings, linear drawings, and photographs; function types, determined by socially anticipated purposes, such as caricatures, publicity pictures, and pornographic pictures; and circulation types, defined by the channels through which pictures are conveyed from a creator to a receiver, such as posters, frescoes, television pictures, and web-page pictures" (Sönesson 1997, 1).

In Fidelity, there is also a thematized tension between artistic image and press photo, act photo and pornography, still images and tabloid reports. "Normally we expect certain construction types, function types, and circulation types to go together" - adds Sönesson $(1997,1)$. The relation between reality and the virtual world of images is permanently reflected in Żuławski’s Fidelity. This issue is put into focus by the inconsistency between the construction, the function and the circulation of those photographs taken by Clélia and Nemo, respectively. The contingent moments of everyday life or the illegal activities need a sort of voyeurism to be registered. These photographs then became extraordinary frontispieces and photo reports in a trash tabloid, after being digitally remastered. The processing is carried out spectacularly on Mac computers, as an ironic and self-reflexive allusion to the more and more aggressive product placement in the movie. All this shows ironically that there is no direct relation to reality, every image is manipulated. Consequently, truth became a sort of fiction. It goes to the autobiographical layer as well, producing a radical uncertainty for the audience, in a reflexive and ironic manner.

\section{Irony and Self-Irony}

Żuławski's film as an adaptation is rather ironic. We meet the figures of the seventeenth century like Clèves, Nemo (Duke de Nemours), or Mme Clèves's mother. The king (MacRoi instead of Henry II), the queen and their lovers are members 
of the management of a media empire which constantly generates sensations as simulacra, supplements. Chevalier de Guise, the young knight who is madly in love with Mme Clèves appears here as the little editor. He is reading and quoting Mme Lafayette's novel, and makes a film on Clélia, using different mirror structures, mise en abymes, just as Żuławski, the director of this adaptation. This comic and pathetic alter ego bears a good portion of responsibility for the ironic effect.

Fidelity's intertextuality is also intertwined with irony, which interconnects the biographical and the aesthetic layers of the reflection, sketching out an implied author-like narrative instance beyond propositions and images. The ironic and satiric character of Auden's old age poetry is well known. Clèves is a fan of Auden's poetry because of its truth, while - in an ironic manner - the title of the tabloid Clélia works for is La Vérité, that is "The Truth." It is hard to tell whether it is a fake or rather a parallel reality when one reads the headline about Fidel Castro's death, appearing as the media context of a bad quality picture which advertises Clélia's photo-reportage. The ironic association points out again the distorting function of mass media. This scene in the movie is followed by a shot in which we see a television advertisement of a photo camera with autofocus, being right the opposite of Clélia's realism. The scene in which Clélia and Clèves go to bed surrounded by her projection-prints can also be interpreted in a metaphoric way, and in that case it would suggest that their love is as unspontaneous and fuzzy as the real life. As a counterpart of the above scene, the real squash match of Clélia and Nemo gives an ironic twist to the virtual tennis scene in Antonioni's BlowUp. [Fig. 12.] Here, they really do it, together.

Besides the aesthetic reflections through background references, another source of irony is the fact that the film is a free adaptation. It provides an excellent possibility to put the contemporary world of the adaptation in contrast with the morals of the French aristocracy of the seventeenth century. In Mme Lafayette's novel, noblesse requires that passion should not rule obligation in any circumstances. The autobiographical background of Żuławski’s film - namely, Sophie Marceau left him for a producer - is suited to interconnect melancholy and social criticism. Traditions, values, and virtues represented by the high culture of Clèves, Auden and Żuławski have become outdated in the accelerated, shallow, virtual world of a consumption society formed by mass media. Nevertheless, Żuławski offers a dialogical and self-ironic structure of meanings in Fidelity since his alter ego is rather a tragicomic figure, formed in an excellent way by Pascal Greggory. Furthermore, the name of the heroine, Clélia, refers to another seventeenth-century French novel, the Clélia of Mlle de Scudéry, often 
considered as a proto-feminist manifesto concerning love. Her allegoric Map of Tender and the debates on the virtuous and constant love may serve as another mise en abyme. The love triangle of Clèves, Clélia and Nemo evokes the story of Valeria, Emilius and Herminius in Clélia. Similarly, the ghost of Clélia's father is conjured up in the film from a point of view which merges Clélia's twinge of conscience and her mother's remorse. Thus, besides the alleged opinion of the implied author, another perspective gets into focus, that one of the woman who wants to "be mistress of her own destiny" (Scudéry 2005, 276), and for this reason she rejects her suitors - constituting a polyphonic narrative structure to dramatize moral ambiguity in romantic love.

Besides the obvious analogies with The Princess of Clèves and Clélia, another work has to be taken into account, Lélia, an autobiographical fiction written by Georges Sand. Obviously, there are important differences between Mme de Lafayette's love story and that of Żuławski. In the latter, Clèves has far more importance, while Clélia had not had an abstinent attitude towards sexuality before the relationship with him. The motive of misunderstanding is central in the novel - it is caused by a lost letter, while the film emphasizes other aspects. As mentioned, the tabloid's editor - as another mise en abyme of the director, since he is also making a movie about Clélia and himself, - often quotes from The Princess of Clèves, but Clélia tells him not to quote. Therefore, she refuses the analogy with Mme de Clèves, telling "I am myself." The figure of Clélia rather evokes Lélia, the burned-out woman whose real-life model was Georges Sand herself. Lélia is a sentimental novel consisting of letters and subjective monologues put together in an autobiographical and allegorical manner. Lélia is a disillusioned thirty-year-old woman - just as Clélia -, who is not able to be in love, to be happy. Sténio is desperately in love with her, but she cannot requite it. Here Sténio is rather analogous to Nemo, emancipating the point of view of the younger teaser in a way.

To sum up, in Fidelity, biographical references and aesthetic reflexivity are interconnected in an intermedial way. This intermediality consists mainly in the different functions of photography. Quotations from Auden's poetry and the Princess of Cleves as hypotext serve as another intermedial link, just like the allusions to Clélia and Lélia, between literature and film. Using this intermedial approach, Żuławski expresses irony and self-irony, and puts such problems into the focus as aesthetic realism, the possibility of narrativization, and more specifically the epistemological problem of subjective perspectives. Finally, another mise en abyme provides us an ironic and at once self-ironic 
stance towards realism when Clélia in a monastery is watching an American TV adaptation of The Princess of Clève, directed by Nemo. It has the same opening scene as Fidelity but the ending represents Nemo's perspective and emotions in a parodistic way. Thus, Żuławski successfully disposes of the semantic limitation attached to the conventional ("realist") linear and referential narrative structure. Self-referentiality, intertextuality, uncertainty and perspectivism result in a multi-referential, open-ended narrative, which requires an active hermeneutical approach from the audience.

\section{References}

Atkinson, Michael. 2008. Exile Cinema: Filmmakers at Work beyond Hollywood. New York: SUNY Press.

Auden, Wystan Hugh. 1969. City Without Walls, and Other Poems. London and New York: Faber \& Faber.

Antonioni, Michelangelo. 2007. My Cinema. In The Architecture of Vision: Writings and Interviews on Cinema, 59-68. Chicago: The University of Chicago Press.

Barton-Fumo, Margaret. 2012. Interview: Andrzej Zulawski. Film Comment March 06. http://www.filmcomment.com/blog/film-comment-interviewandrzej-zulawski/. Last accessed 24. 10. 2015.

Dällenbach, Lucien. 1989. The Mirror in the Text. Chicago: The University of Chicago Press.

Ford, Charles and Robert Hammond. 2005. Polish Film: A Twentieth Century History. Jefferson: McFarland.

Goddard, Michael and Ewa Mazierka, eds. 2014. Polish Cinema in a Transnational Context. Woodbridge, UK: Boydell and Brewer.

Goldman, Peter. 2008. Blowup, Film Theory, and the Logic of Realism. Anthropoetics vol. 14 no. 1 (Summer). http://www.anthropoetics.ucla.edu/ ap1401/1401goldman.htm. Last accessed 24. 10. 2015.

Grishakova, Marina. 2010. Intermedial Metarepresentations. In Intermediality and Storytelling, eds. Marina Grishakova and Marie-Laure Ryan, 312-331. Berlin, New York: Walter De Gruyter.

López-Varela, Asunción and Camila Khaski Gaglia. 2013. Intermedial Serial Metarepresentation in Dickens's The Pickwick Papers. Comparative Literature and Culture vol. 15 no. 7. http://dx.doi.org/10.7771/1481-4374.2390, 
http://docs.lib.purdue.edu/cgi/viewcontent.cgi?article=2390\&context=clcweb. Last accessed: 24. 03. 2015.

Scudéry, Madelaine de. 2005. Clelia, an Excellent New Romance. Ann Arbor, Michigan: University of Michigan. Available online: http://name.umdl.umich. edu/A58876.0001.001. Last accessed 24. 03. 2015.

Sönesson, Göran. 1996. Approaches to the Lifeworld Core of Pictorial Rhetoric.

Visio vol. 1 no. 3: 49-76.

Sönesson, Göran. 1997. Visual signs in the age of digital reproduction. In Ensayos Semióticos, Dominios, modelos y miradas desde el cruce de la naturaleza y la cultura. Proceedings of the 6th International Congress of the IASS, Guadalajara, Mexico, July 13 to 19, 1997, ed. Adrián Gimate Welsh, 1073-1084. México: Pourrua. Available online: https://www.academia.edu/5421835/Visual_signs_ in_the_age_of_digital_reproduction_Post. Last accessed 24. 03. 2015.

Sönesson, Göran. 2003. La fotografía - entre el dibujo y la virtualidad. Significacâo. Revista brasileira de semiótica vol. 20 (noviembre): 81-132. Available online: http://lup.lub.lu.se/record/540257. Last accessed 24. 10. 2015.

\section{List of Figures}

Figures 1-2.
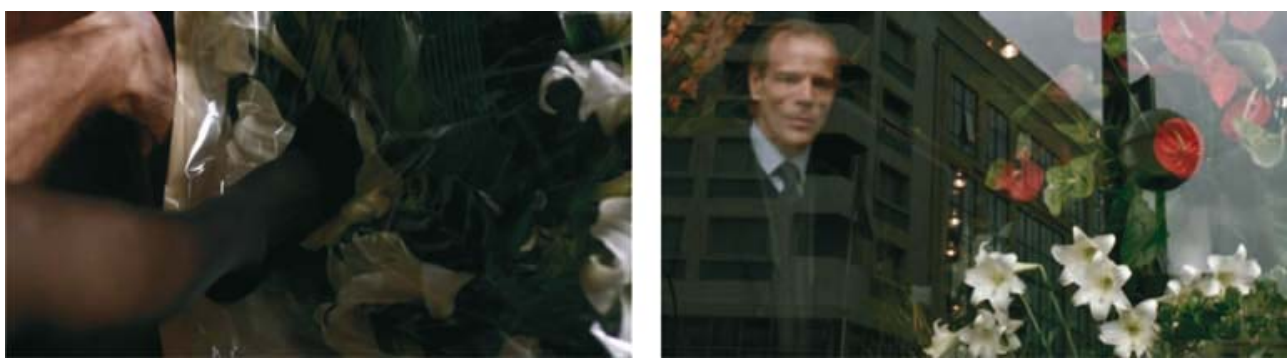

Figures 3-4.
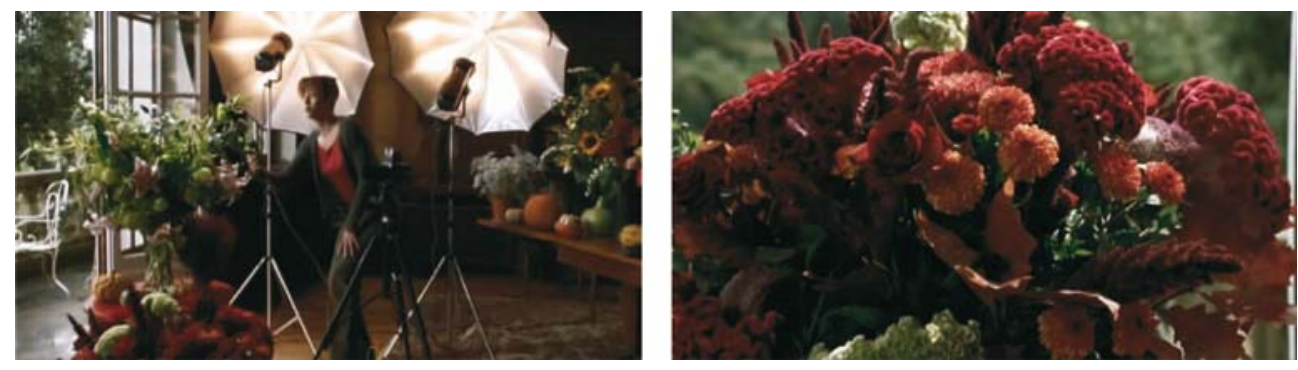
Figures 5-6.

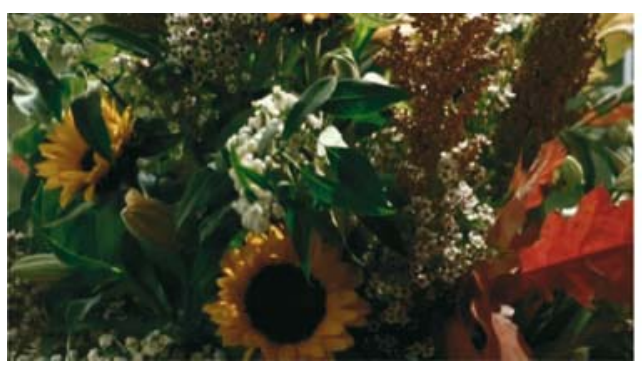

Figures 7-8.
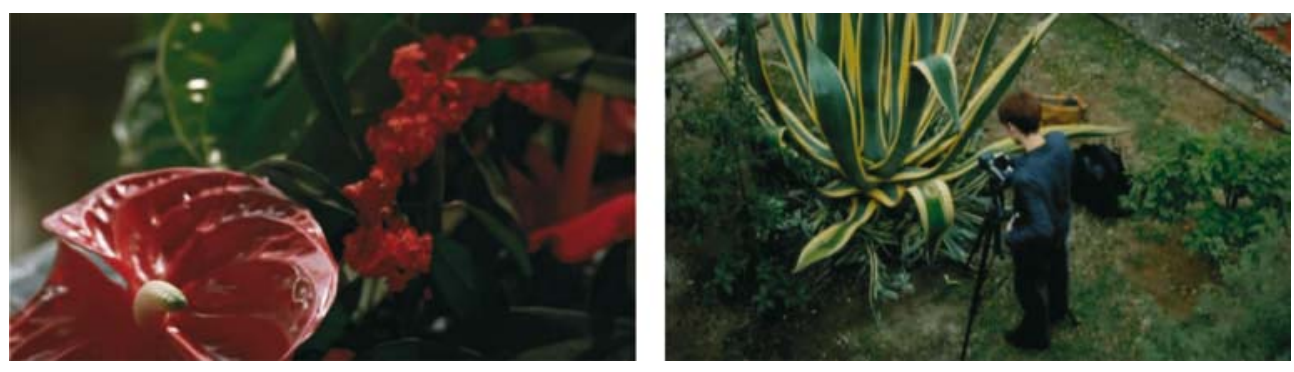

Figures 9-10.
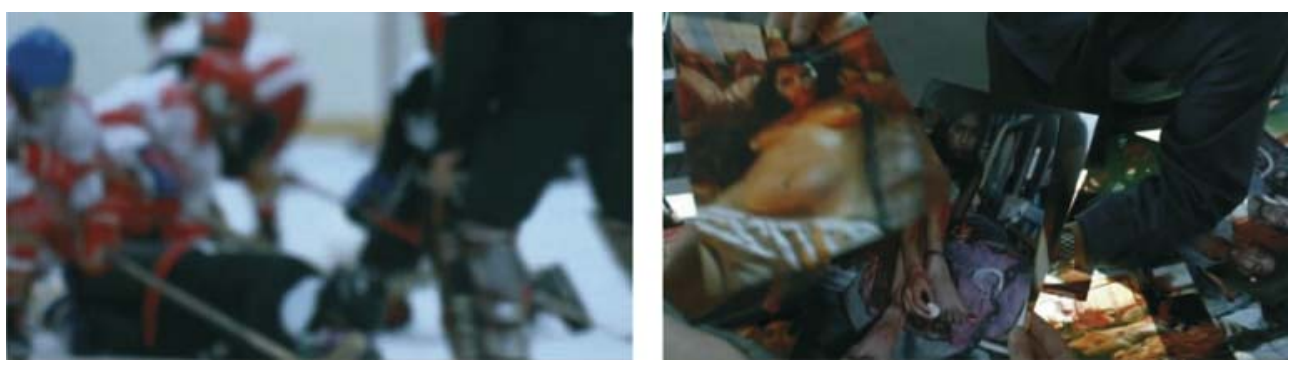

Figures 11-12.
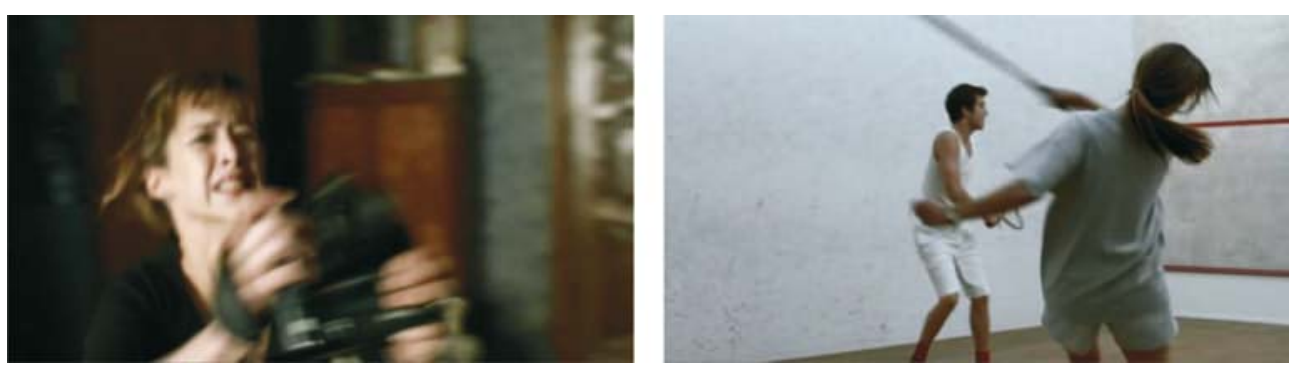